\title{
Networks of phase-amplitude neural oscillators
}

\author{
Kyle CA Wedgwood*', Stephen Coombes, Rüdiger Thul \\ From Twentieth Annual Computational Neuroscience Meeting: CNS*2011 \\ Stockholm, Sweden. 23-28 July 2011
}

In mathematical descriptions of oscillating neural cells, phase reduction techniques can be used to simplify the model to a one-dimensional system [1]. This reduction allows for deeper mathematical analysis of the system, and for simulation of larger networks, since the resulting model is computationally cheaper. However, if a limit cycle is not strongly attracting then this reduction may poorly characterise behaviour of the original system when under forcing, for example, synaptic input. Here we consider a coordinate transformation to a phaseamplitude framework [2] that allows one to track the evolution of distance from the cycle as well as phase on cycle. A number of common models in computational neuroscience (including FitzHugh-Nagumo and MorrisLecar) are revisited in this framework and their response to pulsatile current forcing is investigated. We highlight the differences between phase and phase-amplitude descriptions, and show that the former can miss some substantial features of neuronal response. Finally, we discuss extensions of this work that will allow for the description of networks of limit-cycle oscillators and improve upon the standard weakly coupled phase oscillator approach. In particular, we highlight the merits of piece-wise linear modelling for the development of a theory of strongly interacting systems.

Published: 18 July 2011

\section{References}

1. Kuramoto Y: Chemical Oscillations, Waves and Turbulence. SpringerVerlag; 1984

2. Hale JK: Ordinary Differential Equations. John Wiley and Sons, Inc.; 1969.

doi:10.1186/1471-2202-12-S1-P332

Cite this article as: Wedgwood et al.: Networks of phase-amplitude neural oscillators. BMC Neuroscience 2011 12(Suppl 1):P332.

\footnotetext{
* Correspondence: pmxkw2@nottingham.ac.uk

University of Nottingham, Nottingham, NG7 2RD, UK
}

Submit your next manuscript to BioMed Central and take full advantage of:

- Convenient online submission

- Thorough peer review

- No space constraints or color figure charges

- Immediate publication on acceptance

- Inclusion in PubMed, CAS, Scopus and Google Scholar

- Research which is freely available for redistribution
() Biomed Central

\section{Ciomed Central}

